\title{
Insights on Production End of the Dairy Value Chain in Bangladesh
}

\author{
Abureza M. Muzareba ${ }^{1}$ and Mubina Khondkar \\ University of Dhaka, Bangladesh
}

\begin{abstract}
This research paper aims at critically analyzing the production end of the dairy value chain with a long-run vision and mission to develop a more efficient pro-poor development of value chain that will allow disadvantaged farmers, milkers, feed producers, and feed sellers to overcome barriers and earn more to escape from poverty through further value addition in a sustainable manner. It uses qualitative research with an integrated methodology, comprising in-depth interviews, focus group discussions (FGD), and observation. We collected data from 30 villages located in eight districts in northern Bangladesh, using 44 in-depth interviews and 18 FGDs. Thematic data analysis is used, and five cases are presented. Farmer or producer, milker, feed producer, and feed seller are the production end actors of the dairy value chain. Rearing cows within the homestead is a popular and enduring custom. The labor-intensive rearing lacks automation and needs helping hands. Traditional free-range cattle rearing practice is identified on some river islands. Despite politics in pricing, ethical pricing also exists but not at the institutional level. Hand milking is common practice with vulnerability as it impacts milk quality. Feed selling business is rising and getting institutionalized. Production end value addition scopes are identified along multiple dimensions for stakeholders to take necessary actions.
\end{abstract}

KEYWORDS: Bangladesh, Dairy Value Chain, Feed Producer and Seller, Milk Production, Milker.

Production is pivotal in shaping systematic competitiveness and has considerable influence over the value chain (Kaplinsky \& Morris, 2000). The sustainability of milk production critically depends on cattle health and feed quality (Kiambi et al., 2020; Nyokabi et al., 2021; Phiri et al., 2021; Rasmussen et al., 2021). The milk production system in Bangladesh is not automated and therefore production ecosystem of the dairy value chain has considerable scopes to improve efficiency through advancing feeding, breeding, housing, milking, changing the ratio of costs and income of dairy farms (small, medium, or big), enhancing the performance of both indigenous and crossbred cows, and advancing present technological know-how (Jabbar, 2010). Structurally, small-scale farmers in developing countries face challenges as they struggle to meet the demanded standards which are becoming increasingly stringent due to the increased intervention of institutional processors (Hariyono, 2020; Treurniet, 2021). Gender issues along the dairy value chain are identified in different contexts with varied complexities and in most of the cases, women still lag contributing when decision making is concerned (Haque et al., 2020; Merhaut,2019; Savani

\footnotetext{
${ }^{1}$ Correspondent Author E-Mail: muzareba@du.ac.bd
} 
\& Stewart, 2019; Sikira et al., 2018). These scopes for improvement of the dairy value chain are not only indicating the loopholes of it but also are indicating potentials for further development.

In Bangladesh, the dairy sector is reasonably well organized and functional since the independence in 1971. However, cattle-rearing is usually perceived as an expensive and vulnerable option with pecuniary losses. It was not a popular income-generating activity until the introduction of facilitation projects during the mid-1980s (Garry, 1999), though cattle rearing has been a common social practice among rural people. Northern Bangladesh is well-known for milk production, while the Sirajganj district and the neighboring regions are known as the capital of milk production. High-yielding crossbred and foreign breed cows and low-yielding local breed cows are found there. Commercial milk processors - Milk Vita ${ }^{2}$, BRAC Dairy $^{3}$, and Rangpur Dairy ${ }^{4}$ - have chilling plants in this region.

The dairy value chain can be traced with a clear-cut functional flow and relationship traces. It is characterized by well-defined backward, lateral, and forward linkages. It is diverse with predominant heterogeneity rather than homogeneity across the functional performance of the actors. The diverse characteristics of the country including geographic location as a delta and its changing climate; economic state and poverty situation; a wide variety of farming and gender division of labor; government, non-government organization (NGO), and other institutional patronization through training and finance; cultural norms, values, and religious believes; and bipolar social systems contribute to the diverse nature of its dairy value chain.

Despite the functional flow of activities, the scope of disaggregated activities of different actors, value additions in each stage/level, and trust-based bonds among the actors are well-defined and identifiable; considerable scopes of improvements and enhancements of the dairy value chain are also explicit. The role of trust is particularly emphasized by experts for improvements along the dairy value chain in a developing country (Albrecht et al., 2016). The prominent probable scopes of value addition in the dairy value chain in Bangladesh include developing farmers' technical knowledge, ensuring the use of appropriate technology and flow of information, providing affordable financing and convenient transportation (Rahman et al., 2019). In addition to these, policy and technology interventions are essential to create and/or alter opportunities throughout the value network (Jabbar, 2010). Recently, GoB has formulated blockchain strategies for services, but special attention is needed to integrate the dairy sector with it (GoB, 2020). Existing models in this respect can be useful (Tan \& Ngan, 2020).

\section{Conceptual Framework of the Dairy Value Chain in Bangladesh}

As a conceptual framework, value chain analysis is used to discuss the positions of and interactions among multiple actors in a networked ecosystem to assess scopes of value addition (Jäckering et al., 2019; Kumar \& Rajeev, 2016; Nang'ole et al., 2011). The conceptual framework of the dairy value chain in Bangladesh is grounded in Porter's value chain model (Flanagan et al., 2018). However, instead of analyzing an institution, the framework focuses more on a portion of the network in specific territories where the portion involves actors involved in the production end of the dairy value chain. Similar approaches are also used by many experts (De-Figueirêdo et al., 2014).

Actors in the dairy value chain include farmer or producer, milker, feed producer, feed seller, vet, paravet, AI facilitator, medicine seller, milk collector, middlemen or wholesaler,

\footnotetext{
2 Bangladesh Milk Producers' Co-operative Union started operations in 1974 and its brand is Milk Vita.

${ }^{3}$ BRAC Dairy started operations in 1998 and its brand is Aarong Dairy.

${ }^{4}$ Rangpur Dairy and Food Products Limited started operations in 2004 and its brand is RD.
} 
transporter, chilling plant, informal and formal processor, retailer, and consumer. Among these actors, farmer, milker, milk collector, middlemen, chilling plant, transporter, informal and formal processor, retailer, and consumer are primary actors whereas the others are secondary actors. Figure 1 presents an actor-based flowchart of this dairy value chain.

Figure 1

Dairy Value Chain in Bangladesh

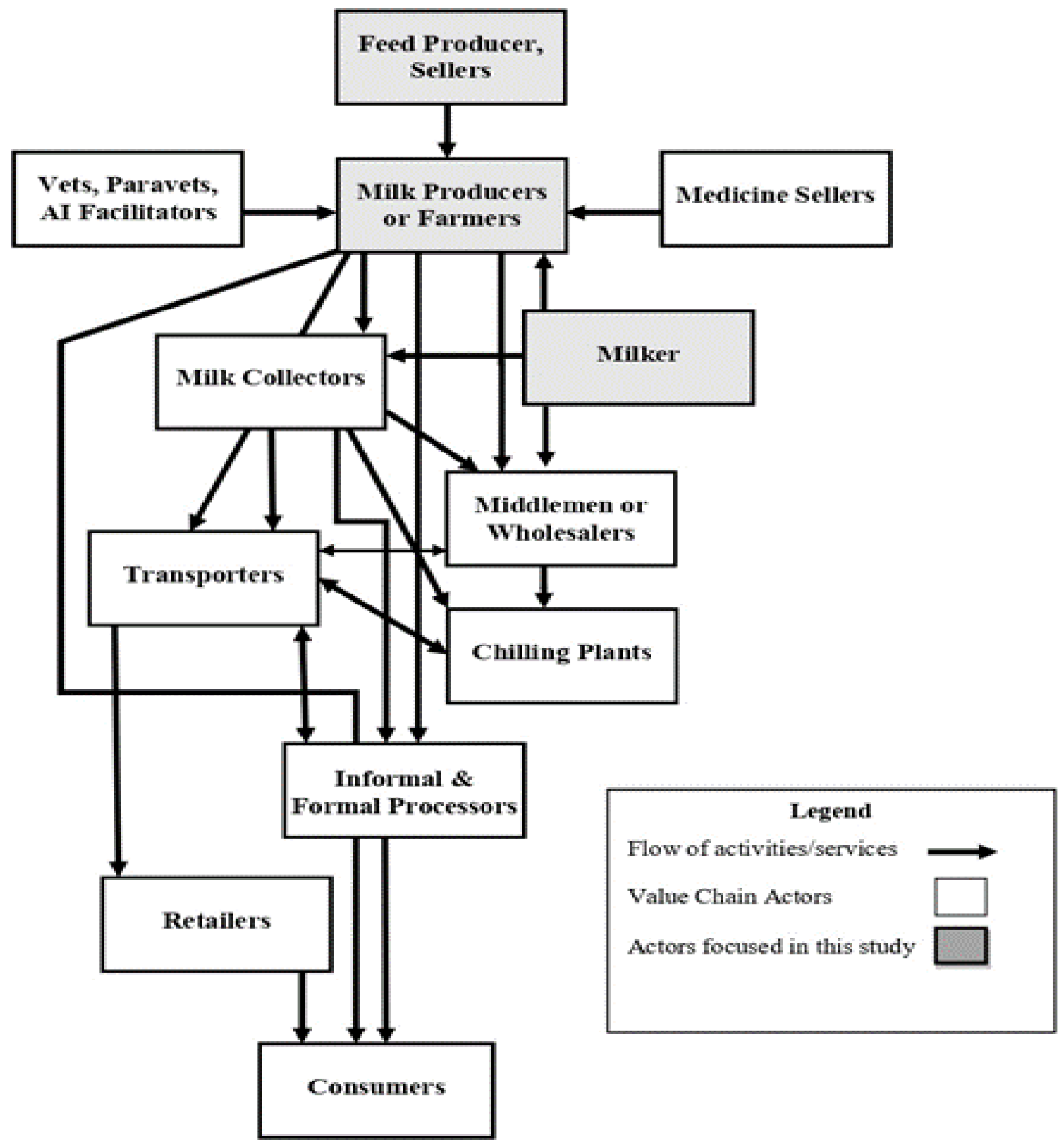

Note. Adapted from "A study on the imperative veterinary and related services providing actors in dairy value chain of Bangladesh: Reflections on some cases," by A. M. Muzareba, 2018, Dhaka University Journal of Management, 12(2) 31-51. 
The value chain involves different types of actors. However, it comprises predominantly small-scale farmers, and value chain related activities are gendered (Muzareba, 2018). Most of the labor-intensive cow rearing activities are performed by women though men enjoy most of the supports provided by community-based institutions for dairy value chain development (Uddin et al., 2020). The major reason for the labor-intensive aspect is the lack of use of technology and related updated knowledge and skills. Small-scale farmers rarely use appropriate technology to assure milk quality, mostly due to a lack of technical knowledge and financing capacity. A similar reality also persists across developing countries (Treurniet, 2021).

\section{Methodology}

We use qualitative research to enable us to better understand and interpret the complex sociocultural and socioeconomic realities facing those involved in the production end of the dairy value chain in the northern region of Bangladesh. Authors are academics and undertook this empirical research because of their interest in value chain analysis and in contributing to literature and practice. Authors' cultural belongingness to Bangladeshi ethnicity positions them as insiders but as they are not local to the case locations, they are to be considered as outsiders, to a degree, to the respondents, turning them into a 'partial insider' state (Sherif, 2001). This state along with their skills in the local language has been useful in developing a trusted rapport with the respondents. While authors' previous experiences of qualitative research in rural Bangladesh and related education and trainings help them maintaining analytical distance, sharing of data analysis with respondents for verification helps them ensuring the validity of the interpretations.

We use in-depth interviews, FGD, and observation methods to collect primary data. While in-depth interview offers the opportunity to gather necessary details of the data; FGD facilitates covering a multitude of aspects of related issues and contexts and gathering cross-verified data, and observation supports the collection of data on naturally occurring behaviors in usual contexts which takes place in the community settings at locations relevant to the research issues. This multimethod approach is adopted to conform to triangulation which is argued to be pivotal in ensuring validity and reliability of data (Silverman, 2015). We consider the persisting context of the dairy value chain to design a sampling approach and use an integrated sampling approach consisting of purposive sampling and snowball sampling. The former approach is used to select case locations ensuring the inclusion of those areas that contribute considerably to the total milk production, and the latter approach is used to identify respondents who are known to have been involved in cow rearing, milking, feed growing, and selling. We contact local opinion leaders such as religious leaders, administrative figureheads, and feed selling stores in the respective villages to identify the initial set of prospective respondents who lead us to find our other respondents who are selected based on their specialized knowledge and unique perspectives as well as the concerned roles they play. We select 30 villages located in eight districts that are recognized for their high contributions to the total milk production. This research includes only small and medium-scale farmers which are supported by the reality that most of the farmers in Bangladesh own at best four cows and about $80 \%$ of the farmers own one or two cows (Choudhury \& Headey, 2018). We conduct 44 in-depth interviews and 18 FGD sessions and Table 1 presents the details. The sample sizes are configured following the data saturation technique. 
Table 1

Respondents' Profile

Respondent Category

\begin{tabular}{cccccccc}
\hline Method & Farmer & $\begin{array}{c}\text { Farmer } \\
\text { cum } \\
\text { milker }\end{array}$ & Milker & $\begin{array}{c}\text { Farmer cum } \\
\text { feed } \\
\text { producer }\end{array}$ & $\begin{array}{c}\text { Farmer cum } \\
\text { milk } \\
\text { collector }\end{array}$ & $\begin{array}{c}\text { Farmer cum } \\
\text { milk collector } \\
\text { cum paravet }\end{array}$ & Total \\
\hline In-depth & 15 & 9 & 5 & 5 & 5 & 5 & 44 \\
Interview & 8 & 2 & 2 & 2 & 2 & 2 & 18 \\
FGD & 8 & & & & & \\
\hline
\end{tabular}

Note. Different categories of respondents and respective sample sizes.

We use a questionnaire for in-depth interviews, a guideline for FGD, and a schedule for observation to facilitate data acquisition. Data formats from in-depth interviews and FGD consist of audio recordings and written notes. We use a thematic data analysis approach to synthesize findings and present five cases on selected value chain actors to present empirical data. A chronicle of themes that emerged from the field data is used to present interpretations, along with a respective actor-specific case to enable readers to validate the interpretations and/or develop their interpretations. Thereby, all three components of a good qualitative inquiry as per Creswell and Poth (2016) are used in this research.

We ensure the anonymity of our respondents to preserve their privacy and safeguard them from any negative consequences. While anonymizing respondents we maintained the male-female ratio of our respondents through a gender-sensitive naming approach.

\section{Discussions on Findings: Value Addition through Strategic Roles of the Actors}

Milk production depends on a range of factors and the primary ones are a type of breed, quality of cattle rearing, quality of feed, and milking procedures followed by milker. These factors incorporate the direct involvement of four value chain actors - farmers, milkers, feed producers, and feed sellers. Relationships among these actors are shown in Figure 1.

\section{Farmers}

Farmers, the primary beneficiaries of the dairy value chain, are those who rear cows, and in this research, we focus only on rural farmers who rear cattle at the homestead in an integrated manner (without any separate arrangement) and those involved either in small-scale or mediumscale farming. A small-scale farm is perceived as an arrangement where a shaded structure is present; which is within the homestead but detached from the house, and a maximum of five cows are reared. A medium-scale farm is perceived as an arrangement where a shaded structure with related facilities is present, but which is not within the homestead and a maximum of 12 cows are reared. Some farmers who rear cows at home in an integrated manner might possess only foreign 
breed cows, but cows are usually local breeds in small-scale or medium-scale farming. The reasons for this pattern are the high price of foreign breed cows, high feed costs, and extensive caring efforts that farmers find difficult to bear. Among these three modes of rearing cattle, rearing at home in an integrated manner is the most popular one treated as an enduring custom with socioeconomic benefits. This practice has been a strong enduring element of rural culture and contributing the most to the total milk production of the country. GoB initiated a project named 'Ektee Bari Ektee Khamar' (one house one farm) to harvest socioeconomic benefits for rural people out of this custom through consumption of and/or sale of milk or, sale of beef cattle (GoB, 2014).

Farmers usually purchase cows either from nearby haat (local weekly market) or bazar (local everyday market). Suppliers of these cows include businessmen involved in cow fattening, government-controlled and private dairy farms, and rural households. Some farmers get cows from local elites who either donate cows or offer cows on conditional rearing known as 'aadi'. In this system, farmers rear these cows and after reproduction, they retain the calves and return the borrowed cows to their original owners. This works like an unwritten rule among villagers and depends on the generosity of those elites. It is also a common rural custom where cows are given as a bridal gift in form of dowry. Given the perceived prospects of cattle rearing, a persisting trend in this era of globalization is - households, with members working abroad and sending remittances, consider investing in expensive foreign breed cows for high milk production and/or high value as beef cattle. Generally, farmers increase the number of cows through natural reproduction or artificial insemination (AI). GoB has inadequate but functional support systems through which it offers AI-related services that have been acknowledged by respective farmers. Some national and local NGOs have also been offering supports to rural people. 'Ektee Bari Ektee Khamar' and '10Taka Farmers' Account' (Taka implies BDT; BDT10 = USD0.12 ${ }^{5}$ ) are two popular initiatives from GoB (GoB, 2014; Uddin et al., 2015) that offer farmers with low-cost loans, and through financial inclusion opportunity, respectively. Some NGOs also have micro-credit programs to lend money for cow purchasing which plays a critical role and has the potentials for enhancing value addition along the chain (Rahman et al., 2019). Some chilling plant owners also offer credits to purchase cows under the contractual clause that farmers will sell milk only to them. Despite efforts from both government and NGOs, there remain places where rural people struggle in different dimensions while rearing cattle and benefitting from that. Some of these realities are depicted in Case 1.

\section{Case 1: Individual's Emotion Encounters Persisting Systematic Challenges}

Nurul is a farmer living in a village in the Sirajganj district. Local people in this village suffer from severe floods every year. They live in poor infrastructural setup and are left out of the grid electricity supply. Nonetheless, they possess the spirit to encounter their disadvantaged realities, and Nurul, a farmer in his early 30 s, is no exception to that. He has the responsibility of maintaining a family of ten members, which constrained him from getting married. He managed to send his six brothers and three sisters to school and finished his college education. He grows crops and rears three cows to earn bread. Regarding his cattle rearing, he shares:

I collect five liters of milk in the morning and three liters in the evening. Milk production is not enough. I must sell milk at the nearby market and

\footnotetext{
${ }^{5}$ BDT85 = USD1, as of 15-9-2020 from https://bb.org.bd/econdata/exchangerate.php
} 
usually cannot save for home consumption. Usually, I look after cows, sometimes my brothers and sisters do that.

Nurul has received training on cattle rearing from a local NGO and has learned tactics from that training and developed related knowledge. He claims:

I know about fat percentage and its implication in the dairy business. I learned about how to make granular feed and it brings good results if given to the cow regularly. The main elements of granular feed are gomer vhushi (wheat husk), khesharir vhushi (lentil husk), tiler khoil (sesame husk) which are useful to increase milk production. Milk gets thin when cows eat water hyacinth, which is bad in terms of business because the price of thin milk is low. ... I believe that if I give less feed, I get less milk.

Nurul also knows about fodder cultivation techniques and he asserts that he has learned these over a decade ago although cultivating fodder has only recently become a known practice. He recently has cultivated fodder on a small piece of land. While he has adequate knowledge of fodder, he has been suffering from managing cattle diseases. He argues:

Torka (Anthrax), Badla (foot-and-mouth disease), Khura (foot-and-mouth disease) are the major diseases. Rot in any organ of the body is the main symptom of Torka, it is also called Pocha Mina. To prevent this, a vaccine is necessary every six months. Badla can usually be discovered after the death of cattle. At least one vaccine is needed every year to keep cows protected but there is no paravet in my village. The vet charges a high price - one injection costs BDT1000 (USD11.76) to BDT1500 (USD17.65).

Nurul's struggles with cattle diseases are unfortunately a common phenomenon for rural farmers (Badruzzaman et al., 2015).

Despite the struggles, cattle rearing is a source of income for Nurul. He usually sells bull during every Eid-al-Adha ${ }^{6}$ and makes a profit. He uses that money to meet his expense and to buy land and cattle. He has sold a cow at BDT70000 (USD823.53) and plans to own hybrid cows to become a large-scale milk producer. He is aware of the challenges that might affect the success of his plan. He said that it is a critical problem to find good quality semen and often he struggles to get cattle medicine and vaccine. Although the market-related systematic problems, depicted in the above statements, limit prospects - Nurul accepts these problems enthusiastically and argues that problems are embedded realities in any business. He opines that with proper planning he must overcome these problems and progress forward.

\section{Cow Rearing Involves Gendered Activities}

Activities involved in cattle rearing are strongly gendered, aligned with persisting patriarchal social reality in Bangladesh (Cain et al., 1979; Chowdhury, 2009; Kabeer, 1988, 1991, 1994; Kabeer et al., 2011). Most women need to take care of the cattle investing long hours, and men get involved only when cows need to be taken out of the house for treatment or other purposes.

\footnotetext{
${ }^{6}$ Religious festival, observed by the Muslims, when cattle are sacrificed as a ritual.
} 
However, men receive about double the support services from dairy-based community institutions compared to what women receive (Uddin et al., 2020). This division of labor is an instance of a gendered role pattern (Chowdhury, 2009; Kabeer, 1994, 1998; Kabeer et al., 2011). So, girls (but not the boys) need to spend most of their time on household activities affecting their schooling and resulting in persisting spiral impacts of gendered roles (Seymour et al., 2020). Sometimes women need to do cattle rearing activities in an unhygienic and dirty environment and without the help of proper accessories. Usually, women work barefooted, do not use handheld tools, and do not wear gloves or protective wearables when they work. Often their activities are facilitated by other household members like sons and daughters and they also work in similar conditions. In the timepoor reality, many of the rural people have a demand for labor to support cattle rearing but either they cannot afford it or there is a dearth of available labor. This situation leaves women overloaded with an extra workload which researchers have identified as a double or triple burden (Momsen, 2008). Dilshad emphasizes the need for a helping hand in rearing cows and her story is presented in Case 2.

\section{Case 2: Cow Rearing is Labour Intensive in Absence of Technology Adoption}

Despite being a member of a relatively solvent rural family in Joypurhat, Dilshad has been struggling to manage her cow rearing. She claims:

\section{I have been involved in milk production and selling for the last 13 years. I have started managing cow rearing with five cows but now I keep only three cows as I am getting older and cannot manage to rear more. I need to do everything by hand and do not get any assistance as my other family members are involved in other income-generating activities.}

It shows that Dilshad needs to manage all the cow rearing activities on her own, which reflects what Momsen (2008) identifies as a double or triple burden of women. While technology is adopted to help humanity get rid of manual labor, this labor-intensive cow rearing at small-scale farming has been pursuing the traditional manual approach.

She has got two AI-facilitated cows as a gift from her eldest son's father-in-law, a common rural custom reflective of dowry culture. These AI-facilitated cows produce more milk, but she also struggles with higher feed costs. She milks the cows herself and then sells milk to a local tea stall. Local milk collectors usually offer a lower price.

\section{Bathan: The Free-range Cattle Rearing}

One unique legendary system naming bathan (cattle colony) exists in riverine rural Bangladesh. It is a cowshed or a place where cattle are housed and maintained. It is a form of agrarian business pursued by professional cowmen who keep his and other rural people's cattle under his care for grazing on community land. They work as a custodian and maintain the cattle in the field and in return receive remuneration from the communities in kind, usually in the form of crops and livestock, or sometimes in cash. Rural people living near or on char (river island) can avail themselves of this option of cattle rearing ecosystem. Usually, rural people take this opportunity due to the lack of helping hands required for cow rearing, while some take this opportunity to get their cattle better fed by naturally grown grass of the char areas. 
Bathan is a nearly extinct agrarian system for community herding cattle in rural areas (Islam et al., 2003). The role of the cowmen of bathans became unknown to many people as this concept became almost extinct in this country. Some factors that have been intensifying the declining trend can be attributed to persisting power structure as cowmen are not influential, river island is lucrative for crop production, bathan is not financially lucrative for owners or, even for the hired laborers because of pressing market price and an absence of a sense of fair trade. Although the trend of bathan declined, clear evidence is there that rural people still need its services and can benefit from it because in some areas people cannot rear cattle due to the lack of adequate manpower. Therefore, there is scope to redefine the necessity of bathan and organize this sort of service, if possible, in a better managed and facilitated form for those who are badly in need of assistance to tend their cattle. While women farmers cannot avail the opportunity of owning a bathan due to persisting patriarchy and conservative socio-cultural norms, bathan can offer women to take the opportunity of cattle rearing in an indirect but functional manner. With the spirit of free-range cattle rearing, a sophisticated value can be added if formal approaches are taken to tap this well-known means of cattle rearing. Marketers need to recognize this value addition opportunity, pursuing what would not only reinforce cooperation from respective backward linkages but also would help them offer supporting hands to household level farmers who are identified by Prahalad (2010) as the bottom of the pyramid. Free-range, known as a premium level value addition through the marketing lens (Van et al., 2014), could thus be an effective strategic value addition opportunity with positive social and economic impacts in the dairy value chain.

\section{Feeding, the Dominant Scope for Value Addition}

Feeding is an integral part of cattle rearing which has direct and immediate impacts on production quantity and quality; and thus, has the most dominant scope for value addition. Farmers feed cattle a range of items but what they feed mostly depends on - what they grow, their knowledge about different feeding options and their impacts, their financial ability, breed of cow, and distance of their house from the local market from where they can buy cattle feed. Farmers generally feed their cows straw, grass, cornflower, oilcake, salt, rice, broken rice, molasses, crushed husks of paddy, wheat, lentil, and sesame. This variation in categories depends on crops that are cultivated in their lands and their locality. Innovative farmers, out of their wit, test different combinations of vegetables and produce they grow and occasionally get a positive result. Cabbage grower farmers use cabbage as cattle feed and receive good results in increased milk production. However, this wit test does not always bring a positive outcome. In the spirit of being innovative, sometimes farmers use various crop and vegetable leaves as feed that are poisoned with insecticides and/or other chemicals they use to optimize crop production, and this causes harm to cattle health and sometimes causes death. While it is found that this contamination can affect milk quality, it is proven that milk coming from small-scale farmers have considerably low antibiotic residues than milk coming from larger farms (Orwa et al., 2017).

Farmers who own lands, where they can grow green grass, can offer it to their cattle. Only a few well-off farmers can afford Napier grass, traded at the local market. Farmers, who have no land or no way to manage green feed, usually rely on dry straw and naturally available grass. Farmers claim that feeding naturally grown grass is one of the best means to ensure high quality and quantity of milk production. A crucial problem for the farmers who suffer from economic poverty is the distance between their houses and the local nearby market from where they can purchase cattle feed and medicine. Commuting to a distant market needs money, time, and efforts which those in economic and time poverty struggle to manage. They also cannot enjoy savings 
through bulk purchases because corresponding opportunity costs are challenging for them to afford. A distant market and poverty situation together cause delayed supply of food and/or medicine, resulting in negative health impacts on the cattle which lead to less milk production. A greater amount of feed is required regularly for crossbred or foreign-bred cattle, which requires increased spending on feed, and those in poverty find it further challenging. Thus, economic poverty and the high price of cattle feed and medicine create a vicious cycle that must be broken to improve milk production at the household level.

Feeding is intricately connected to cattle health and has significant impacts on value addition. While farmers identify feeding as a dominant scope for value addition, they also assert that taking proper care of the cow is equally important as that transforms the effects of a good feed. Farmers having poor knowledge about cattle diseases in the given reality where government veterinarians are scarce, usually detect cattle diseases mostly by identifying irregularities in feed taking and/or observing noticeable symptoms. Most farmers believe that cows have feelings and so during the winter, they cover cows with a sack to keep them warm and make them feel comfortable. They claim that this care usually results in increased production of milk which inspires them. Some farmers believe that naming cows and calling them by name keep cows happier. These beliefs are supported by experts who identify ethical senses in pursuing this course of action (Albright \& Arave, 1997).

Human efforts at household level cattle rearing can optimize milk production, with respect for ethical senses, which are evident in the above discussions. For the majority of farmers, these resulting positive effects are conditional and those depend on nature. Despite considerable efforts in feeding and care, milk production remains remarkably low for local breed cows which is attributed to the genetic properties of the cows (Khan et al., 2009). There also exists a seasonal variation in milk production during the winter and rainy seasons, which is attributed to available feeding options. An ample supply of naturally grown grasses becomes available during the rainy season, and as most of the farmers cannot afford grass production on their own, they can avail this free feeding opportunity. However, one exception exists in this season when floods break in and inundate low regions. During a flood, the affected regions have barely any place abounding grass and the remaining few high lands remain occupied only for shelter to survive for both humans and animals. So, the rainy season appears as a blessing for some, but a difficult time for flood-affected regions. Therefore, although the rainy season offers abundant water and green grass for the cattle to drink and to eat, an opportunity for a convenient cattle-bath to keep cattle clean, and a natural wash to maintain cowshed tidy; those farmers affected badly by flood struggle to maintain their regular care for the cattle and offer adequate feed to them. Institutional initiatives from GoB and NGOs can help farmers minimize losses caused by natural disasters and maintain adequate feeding, and this opportunity of value addition is inadequately addressed.

\section{Politics of Milk Pricing}

Milk price is determined by the quality of and demand for milk, though relationships among price, quality, and demand are not straightforward and rather complex to a considerable degree which can be attributed to the market structure and power relationships among the value chain actors. Household-level farmers usually are not empowered to enjoy pricing the milk they sell, be it selling the milk to middlemen or selling directly to consumers at the marketplace. While the latter can be justified by the characteristics of the market where the market determines the price, the former is caused by a power imbalance when middlemen control the pricing mechanism. Due to persisting information asymmetry between farmers and middlemen - regarding the factors that 
shape milk pricing and the persisting lack of farmers' knowledge about milk processing techniques to preserve milk in circumstances of lack of sales - farmers need to bear the losses due to lower price.

Farmers sell milk to individual consumers, wholesalers, sweet shops, tea stalls, chilling plant agents, and/or milk collectors employed by chilling plants. Despite a range of buyers, a stable selling price comes with the risks of losing a fair price unless the buyers are small-scale business entities such as local tea stalls and local sweet and posset makers. In the case of small-scale businesses, the quality of milk needs to be noticeably good to convince buyers to agree to a stable fair price. Quality here implicates market-perceived notions of quality rather than performance quality which is used by formal institutions. The other option to get a stable selling price for farmers exists when chilling plants reach out to farmers either directly or through third-party collectors under long-term contracts. Milk quality in this case only needs to meet the official standard (performance quality) which is having a fat percentage of three or above and farmers receive payments usually after a month. Instead of counting on the fat percentage of milk provided by the respective individual small farmer, the milk price for every individual farmer is determined based on the average fat percentage of the total 30 liters of milk that is required to fill the large container to carry milk to respective chilling plant. This happens because milk collectors generally do not have the kit required to measure the fat percentage of milk which is measured only at the chilling plant. The poor condition of the fat percentage measuring device at most of the chilling plants reveals that respective devices are seldom used which implies that farmers usually receive a milk price based on approximation than actual fat percentage measurement. When third-party collectors collect milk then farmers risk double deprivation of fair price because, in addition to the abovementioned questionable measures for price estimation at the chilling plant, collectors use lactometer or observational assessments to determine milk quality and price which for the former approach is conflicting. After all, lactometer measures only density whereas price is determined by fat percentage as per the traditional performance quality measures in Bangladesh, and the latter approach is prone to subjective judgment. Lack of use of technology for milk quality assessment is one reason underlying the exploitative pricing mechanism which needs farmers to have technical knowledge and affordability to be get resolved (Treurniet, 2021).

Sometimes farmers sell milk to chilling plants on short-term contracts such as on weekly basis and then milk price is determined based on both fat percentage and current market price. This critical role played by market price is also highlighted by other experts (Rahman et al., 2019). Farmers receive their due payments after a week and sales amount records are generally kept only at chilling plant end in log files. Nonetheless, the scope for the double deprivation in milk price remains the same and even with added risks of market volatility of milk price. Some farmers are often bound to a forced sale to specific milk collectors or specific chilling plants at a price usually lower than the contemporary average market price when they take loans from buyers under strict sales conditions. Farmers usually receive a better price compared to the price they receive from chilling plants or their designated collectors when they sell milk to milk collectors who are under no obligation to any chilling plant. This implicates that chilling plants need to pay higher milk prices than the price they usually offer to farmers or chilling plant designated collectors when they need to buy milk from these independent collectors. These independent collectors enjoy the bargaining power of fixing milk prices which farmers usually do not have at any time. This exploitative entrapment in what the farmers are in is a structural problem that can be effectively addressed by government interventions aiming at market monitoring, formulation of effective policies, and their implementations. One untapped strategic value addition opportunity along the backward linkages for chilling plants or, commercial large-scale processors is when fair-trade 
policies are adopted which could ensure fair milk price for farmers. Outreach plans can be considered to capitalize on this untapped value addition opportunity.

Selling prospects and related scenarios also affect milk pricing. Milk transport facility, when remains vulnerable, sometimes leads to compulsive local sales which get farmers poor milk prices. The lack of available information on respective market demand is another factor that impacts price. This remains an untapped opportunity for critical value addition in the dairy value chain. These issues related to the influence of transportation and information flow on the value chain are also identified by other experts (Rahman et al., 2019). Institutions need to work on providing information about market demand for milk to farmers so that they can match demand and do not face demand-led unexpected price changes. Milk preservation facility using a fridge at the household level can help farmers manage milk supply during a sharp demand decline but for a short time. Demand decline usually comes from changing demand at formal processors' end (chilling plants) who are few and are the most large-scale buyers of milk. Although liquid pasteurized ultra-heat-treatment (UHT) milk is the main product those processors sell along with other dairy products such as butter and yogurt; there exists an emerging market in Bangladesh for cheese that can have a comparatively longer shelf life. Manufacturing cheese can help manage demand fluctuations of liquid milk if local level small and medium enterprises (SME) can be established. This proposition of value addition is grounded in the fact that although formal processors manufacture different types of cheese, there exists popularity of locally manufactured cheese that is considered as heritage cheese. This formal cheese manufacturing initiative might also help manage milk selling hurdles caused by a high degree of perishability, extreme weather, natural calamity, varying demand, transportation facility, and challenging distance from the market. People living in islands who are facing challenges due to vulnerable and poor transportation might benefit from this. This initiative can also relieve farmers from forced sell at a lower price, wastage, and getting milk sour due to no sale or prolonged inappropriate preservation. There exists a sophisticated value addition opportunity embedded in this initiative as it would help farmers manage the short life of fresh milk and avoid resulting consequences which some of them often manage by adulteration - the alluring malpractice of mixing some chemicals locally called medicine - to keep milk fresh for a long time. Case 3 represents the experience of rural farmers and the consequences of pricing mechanisms.

\section{Case 3: Ethical Pricing Prevails at Non-Institutional Level}

Mamtaj never let poverty take her smile away. She is a married woman living in a remote village in Kurigram district. She owns two cows and a calf. She sells milk after milking on her own through most of her family expenses are met by income generated through crop production. Her cows are of local breed and so milk production remains relatively low. However, half of the milk is consumed at home and the rest is sold to the nearby market with the help of a local collector. The collector uses a lactometer to measure adulteration when he impugns the purity of the milk through observation. She depends on the collector for volume measurement and price calculation, which is induced by the trust-based social relationship. She even does not keep any record of her transactions with the collector as she trusts the collector. She argues:

He (the collector) keeps records in his notebook. I rely on him and trust my memory. I receive payments twice a week and have never faced any problems regarding price. 
Mamtaj is not aware that milk price at the institutional level is fixed based on fat percentage. While one might argue that this lack of awareness could be associated with the existence of the notion of trust in the collector, the ground reality is that - local people, irrespective of their level of education, have blind trust in the collector. This sort of trust can be thought of as the social relationship-led trust which Granovetter (1985) argued for. The reason behind this trust can be attributed to the simplicity trait of local people.

She gets BDT23 (USD0.27) for each liter of milk and is indifferent to any change in price. Although she is not curious about changes in milk price, she knows that milk collector sells the same milk at BDT32 (USD0.38) per liter with a considerable profit margin. She is not only indifferent to this but also shows strong positive acceptance of this. She empathically accepts the profit-making motive of the collector despite her poor income through milk sales. She argues that the milk collector needs to make this profit as he must take care of his family's expenses. This empathetic approach from Mamtaj evidences the persisting supportive social bonding among members of a rural community which sometimes results in compromising own benefits and preferring benefit sharing. This phenomenon reflects the collectivist social reality which is also claimed by experts (Deci \& Ryan, 2008; Devine et al., 2008).

\section{Government Financing is Trusted and Preferred}

Some farmers are thinking of an increasing number of their cows to increase income. They cannot materialize their desire due to lack of disposable income, and they need credit which is also identified by other experts (Rahman et al., 2019). Some chilling plants and concerned government bodies have their respective programs to meet this demand for loans, but most farmers are not interested to take loans from chilling plants due to accompanying compulsive sales conditions that deprive them of getting a fair price. Government loan initiatives are not successful in an expected manner to attract a good number of clients due to poor marketing initiatives. However, rural people are found to be inclined to get assistance of any kind - be it loan, training, or another arrangement - from the government as they have trust in the philanthropic philosophy government pursues which Mazzucato (2015) argues with the same spirit.

Considerable value could be added to the dairy value chain by offering financial assistance to farmers enabling them to pursue cattle rearing in a more structured and systematic manner with greater effectiveness. The means of financial assistance need to accommodate contextual reality to facilitate the effective distribution of this assistance. GoB should take an effective grounded approach to inform farmers of the support services provisions and arrange convenient means for them to avail themselves of those. To ensure effectiveness and fairness, other related institutions need to design their financial assistance programs excluding forced sales conditions at lower than the respective market price. Despite rural people's trust in government, a flaw is identified in the government's operational strategy for the agriculture sector that has been affecting farmers, particularly marginal ones who are involved in small-scale farming and are not identified as farmer leaders and expert farmers. Government interventions usually target farmers owning large-scale or medium-scale farms and/or farmer leaders and/or expert farmers for operational efficiency purposes, but this approach results in exclusions of marginal small farmers. While the government's such approach is formally justified by an assumption that beneficiary farmers would facilitate trickle-down positive impacts but, that assumption is found ineffective in the ground, creating rather a vicious cycle of exclusion of marginal farmers. 


\section{Milker}

Milking is one of the vital processes in the dairy value chain and the person involved in this process is known as a milker, locally called Goala. Hand milking is a common practice in Bangladesh while machine milking is only found at large dairy farms. Limited use of technology for milking at small-scale farming level is an impediment to value addition which large-scale farmers do not suffer from (Treurniet, 2021). While the quality of milk is strongly related to the breed of the cow, quality of fodder, and health of the cow; quality degradation due to lack of hygiene and contamination is caused mostly by the milking process. Even good-quality milk produced by a cow can get contaminated during milking and create a health hazard (Millogo et al., 2010). Thus, milking offers strategic scopes for value addition by ensuring a hygienic process of milking.

Sometimes female household members need to do milking even though male household members are the farmers. While subordination of female household members is the reason for this (Chowdhury, 2009; Kabeer, 1994; Kabeer et al., 2011), but people often perceive that women can handle the milking process more effectively due to their higher patience and care. Household members, who play the roles of a milker, believe that caring touch and soft milking approach keep cows happy and healthy and increase milk production. Milkers of household-level farmers unlike the dairy farm keep the calves near the cow while milking because they believe that doing this makes the cow feel less stressed, more comfortable, and ensure more milk, and these beliefs are also supported by existing literature (Catlette \& Hadden, 2001). However, due to lack of expertise and absence of helping hands farmers hire professional milkers who are predominantly male. Nevertheless, this profession is on the decline due to poor income prospects. Some of these professional milkers also play the roles of milk collectors and carry milk to sell to the next dairy value chain actor. Milk collectors often play the role of milker to ensure milk quality and to get rid of the riddle of trust regarding adulteration. This milking service, offered by the collectors, convinces respective farmers to sell milk to them.

Farmers sometimes play multiple roles and do the milking on their own to save expenses. It is also common that another member of a farmer's family performs milking and it not only gives them economic gain but also involves a comfortable experience for their cows during the milking process. This approach also helps farmers to avoid possible exploitation that could take place while taking this service from a professional milker with questionable ethical standards. It is argued by some value chain actors that milkers sometimes mix medicine to keep milk fresh for a longer period. Sometimes they trick and deceive while measuring milk. It is alleged that sometimes milkers milk cows according to their demand and so cows remain prone to be over-milked or undermilked, affecting the health of the cow and depriving the farmer of better earning in the long run. Overmilking can also affect the health and growth of the claves which might have considerable long-run economic consequences for respective farmers. However, generally, farmers raise no question about the integrity of the milker, though overall analysis of the value chain unveils the pitfall that abuse and malpractice often start from the milker. Strategically, the milker is an important actor in the dairy value chain because value addition is influenced to a considerable degree at this level. Some realities related to the milker are depicted in Case 4.

\section{Case 4: Awareness Contributes to Value Addition}

Shahinur, a married woman in her early 30s, lives in a village in the Sirajganj district wearing a representative figure of other farmers in her locality. She maintains a family of seven 
members with her husband as the only earning member. She has a herd of seven cows with three cows providing on average five liters of milk each day. Despite her low literacy, she has developed knowledge of the impacts of fodder on milk quality and skills in making fodder. She has been milking cows for a decade and has developed expertise through experience, local knowledge, and knowledge shared by a local NGO. She knows that grass as fodder can enhance milk quality, but she cannot afford it because of her disadvantaged economic condition. Despite limited sources of income - coming from her husband's income and milk sales - she manages to buy grass from the local market. She argues:

I know about the special high-growth grass-Napier. It helps increasing milk production and quality, but I cannot afford it. I buy fodder ingredients separately and mix those to make fodder to save money. I think if we could buy grass in a group that would reduce our cost and we could buy Napier.

She is aware of the best practices of milking and pursuing those religiously. She cleans her hands with soap before milking and uses mustard oil over the teats of the cows to offer comfort during the milking process. She uses a clean milk pot and tries to offer the cows a comfortable experience while milking. She says:

Caring milking not only results in increased milk production but also keeps cows happy. I learned it from my neighbors. I keep the claves near the cows when I milk them, and this keeps cows calm and I get more milk. I avoid overmilking as it affects cow's health and milk quality. This is important that we do not over milk our cows but professional milkers sometimes do it for more income.

It indicates that Shahinur is aware of the issues related to milking and is concerned about the ways professional milkers might affect the health of cow and milk quality through irresponsible milking. Awareness about the best practices of milking among milkers and farmers is a key factor to enhance value addition through milking.

\section{Feed Producer and Feed Seller}

Feed producers and feed sellers play vital roles in milk production (Hemme et al., 2004). Feed producers grow Napier grass and/or process or manufacture feed on a commercial basis. While Napier grass is sold in an open market, packed feeds are generally sold at the grocery. Even 15 years ago, mostly large-scale farmers used to buy feed, but now medium and small-scale farmers also buy fodder (Hemme et al., 2004). Our data also match these claims. The significance of feed producers and feed sellers is increasing as farmer-level involvement in producing or managing cattle feed is decreasing. Increased demand for crops is causing lesser use of land to produce cattle feed. The tendency of rearing crossbred and foreign-bred cows is creating opportunities for feed producers and sellers because demand for compound nutrients is increasing as these cows need more feed and nutrients.

Feed producers include Napier grass growers; molasses producers; rice mills and other mills that produce crushed husks of paddy, crushed husks of wheat, crushed husks of lentil, sesame husks, broken rice, and cornflower. Another category of feed producer produces packed feed of compound nutrients that is mostly used for foreign-bred cows. The packed feed manufacturing 
industry has evolved in Bangladesh since the late 90s, though traditional modes of feed production are still the most common practice. There exist potentials for further innovations in these traditional modes of cattle feed production. Fishpond sediments used in fodder grass production contribute positively to milk production (Haque et al., 2016) though evidence of animal and human anthrax, which were caused by contaminated feed, also exist (Fasanella et al., 2013). Therefore, the roles of feed are pivotal in milk production.

Most of the feed producers and sellers are found to maintain the least hygiene measures. They argue that animal feeds do not get infected even if maintained with the least care for hygiene. The price of most of the feed items has increased because those are processed from crop or crop husks and the cost of crop production has increased considerably. It is also found that feed sellers are mostly grocers, if not the agents of feed manufacturers, and they sell food for both humans and animals under the same roof. There exists an economic rationale behind this approach but at a cost of probable human health hazards. There exists evidence of human health issues through pathogen contamination; however, our research data remain inconclusive regarding this claim (Oliver et al., 2005; Gizachew et al., 2016). Pathogens can contaminate feed, despite its natural sources, when raw materials/crops get contaminated. This can cause considerable human health hazards if milk is consumed without pasteurization. Case 5 provides evidence of scopes of further value addition through cattle fodder in the dairy value chain.

\section{Case 5: Business is on the Rise}

Sabuj has a small cattle feed shop on the outskirt of Rangpur city corporation. He makes his cattle feed to sell both to farmers and traders. He processes crop husks to produce cattle feed using his high-capacity machine. He has an assistant to help him with producing and selling cattle feed. However, neither Sabuj nor his assistant is concerned about health and safety measures while operating the machine.

Demand for cattle feed is high and it is a good profit-making opportunity in his locality. Therefore, Sabuj is finding his business lucrative and growing. He believes that locally manufactured feed is comparatively better for local cattle and it best suits the local environment as well. However, this is only his intuition and he does not have any knowledge to explain his point of view. He shares:

My experience of buying the best cattle feed ingredients helps me produce a good quality feed which ultimately pays off and helps me make a good amount of money. I maintain good relationships with business owners and others. This helps my business to grow and now I have about double the customers I used to have six months ago.

The feed selling business is thus contributing to the development of social capital for Sabuj, like for others who are in a similar business. Although many businesses face challenges and go through ups and downs, as cattle rearing is an integral part of rural culture in Bangladesh cattle feed selling can predict a relatively smooth business.

\section{Summary of the Findings and Conclusions}

This research paper portrays the existing milk production scenario of the dairy value chain that might help to streamline it in a homogenous structured format, as doing so needs a better 
understanding of the current state to identify where and to what extent changes are required. To a degree, milk production and selling are still perceived as profitable businesses by rural people. This profit gain can be maximized if different activity levels of cattle rearing can be owned and controlled single-handedly without sharing with intermediaries. This perception is the main reason for the presence of multi-role players in the dairy value chain. A holistic strategic approach is pivotal to ensure linkages among dairy value chain actors to bind them into a larger whole of marketing processes. Specific focus is advocated on transportation, the flow of information, and technology adoption (Rahman et al., 2019).

The main reason for cow rearing is milk production, although it is found that some people rear cows as an asset which they can liquidate when required (Ahmed et al., 2009; Quisumbing \& Roy, 2014). Generally, poor farmers cannot consume milk at home and need to sell the whole of it. Therefore, although they are the prime initiators of dairy milk production, they can hardly afford that milk for their children or family members. Along with poverty, the absence of a strong tradition of milk consumption at the household level can be attributed to this reality (Choudhury \& Headey, 2018). Cow rearing at small and medium-scale farming has predominantly been a gendered activity that has been overburdening household women across generations (Seymour et al., 2020). It can thus be argued that there exists a significant scope of lateral value addition along the social and gender dimensions which might have long-term social, economic, and business level impacts.

Low milk-producing areas attract a smaller number of collectors and a smaller number of participants of formal dairy processors which eventually results in lesser milk selling potentials for respective farmers. This structural flaw needs to be addressed through strategic value addition but because of low commercial prospects, these areas attract hardly any commercial value chain actor. GoB needs to come forward with institutional interventions to ensure a fair price for farmers. This is because government ideally does not chase profit and never leaves its people behind even if staying with people makes a loss for it (Mazzucato, 2015). The following policy implications can contribute to further research and policy formulation.

- Value chain analysis can work as a policy instrument to identify scopes of improvements and changes (Kuijpers 2020). Policymakers need to incorporate this tool and respective outcomes while formulating dairy-related policies, though some of the policies in Bangladesh themselves, particularly related to breeding, work as barriers to enhance value additions along the dairy value chain in a sustainable manner (Jabbar, 2010). Future research can assess whether the existing milk production-focused breeding policy is sustainable and ultimately beneficial for the country in the long run.

- Appropriate training and market restructuring could assist small-scale and medium-scale farmers in consistently ensuring the hygienic quality of milk and similar arguments about developing countries are also made by experts (Treurniet, 2021). Further research is required to figure out how these training and knowledge development initiatives could be made in a socially embedded manner for greater sustainability.

- Capacity development of the actors along the value chain through training and advocacy of dairy-related SMEs can be arranged. GoB might formulate related policies.

- Blockchain might be effective to enforce and monitor milk quality at the production end (Tan and Ngan, 2020) but given the high percentage of small-scale farmers and the level of the overall economic strength of the country, and its poor infrastructure, the high-tech measure is yet to be a good fit in this country. 
There exist considerable scopes to modify and upgrade the composition of current cattle feed and enhance milk production. Bangladesh Agricultural University and crop research institutions can innovate supplementary cheaper cattle feed which eventually can add significant value. Effective use of fodder can also have significant positive impacts on milk production; both in terms of quantity and quality (Manso et al., 2016). However, these enhancements in cattle feed categories and their quality cannot always be expected to be cheaper, and farmers might need to invest more in their cattle feed to get a higher return. GoB, formal processors, and development partners should take measures to support farmers financially and with related knowledge, which are claimed to be pivotal by experts (Treurniet, 2021), to help them adopt modified approaches to cattle rearing and milk production.

\section{References}

Ahmed, A. U., Minten, B., Quisumbing, A. R., Roy, D., Khondkar, M., Muzareba, A. M., \& Data Analysis and Technical Assistance Limited. (2009). Evaluating the dairy value chain project in Bangladesh: Baseline report. International Food Policy Research Institute (IFPRI).

Albrecht, J., Lelea, M. A., \& Kaufmann, B. (2016, September 18-21). Trust as integral to multistakeholder processes for dairy value chain improvement. Solidarity in a Competing World Fair Use of Resources. Tropentag, Vienna, Austria.

Albright, J. L., \& Arave, C. W. (1997). The behaviour of cattle. CAB international.

Badruzzaman, A. T. M., Siddiqui, M. S. I., Faruk, M. O., Lucky, N. S., Zinnah, M. A., Hossain, F. M. A., \& Rahman, M. M. (2015). Prevalence of infectious and non-infectious diseases in cattle population in Chittagong district of Bangladesh, International Journal of Biological Research, 3, 1-4.

Cain, M., Khanam, S. R., \& Nahar, S. (1979). Class, patriarchy, and women's work in Bangladesh. Population \& Development Review, 5(3), 405-438.

Catlette, B., \& Hadden, R. (2001). Contented cows give better milk: The plain truth about employee relations and your bottom line. Saltillo Press.

Choudhury, S., \& Headey, D. D. (2018). Household dairy production and child growth: Evidence from Bangladesh. Economics \& Human Biology, 30, 150-161.

Chowdhury, F. D. (2009). Theorising patriarchy: The Bangladesh context, Asian Journal of Social Science, 37(4), 599-622.

Creswell, J. W., \& Poth, C. N. (2016). Qualitative inquiry and research design: Choosing among five approaches. Sage publications.

De-Figueirêdo Jr., H. S., Meuwissen, M. P. M., \& Oude-Lansink, A. G. J. M. (2014). Integrating structure, conduct, and performance into value chain analysis. Journal of Chain \& Network Science, 14(1), 21-30.

Deci, E. L., \& Ryan, R. M. (2008). Hedonia, eudaimonia, and well-being: An introduction. Journal of Happiness Studies, 9, 1-11.

Devine, J., Camfield, L., \& Gough, I. (2008). Autonomy or dependence - or both? Perspectives from Bangladesh, Journal of Happiness Studies, 9, 105-138.

Fasanella, A., Garofolo, G., Hossain, M. J., Shamsuddin, M., Blackburn, J. K., \& Hugh-Jones, M. (2013). Bangladesh anthrax outbreaks are probably caused by contaminated livestock feed. Epidemiology \& Infection, 141(5), 1021-1028.

Flanagan, D. J., Lepisto, D. A., \& Ofstein, L. F. (2018). Coopetition among nascent craft breweries: A value chain analysis. Journal of Small Business \& Enterprise Development. 
Garry, M. L. (1999). A people's history of development: 25 years in Northern Bangladesh. University Press Limited.

Gizachew, D., Szonyi, B., Tegegne, A., Hanson, J., \& Grace, D. (2016). Aflatoxin contamination of milk and dairy feeds in the Greater Addis Ababa milk shed, Ethiopia. Food Control, 59, 773-779.

GoB. (2014). Monitoring Report 2014: National Food Policy Plan of Action and Country Investment Plan. GoB.

GoB. (2020). National Blockchain Strategy: Bangladesh. GoB.

Granovetter, M. (1985). Economic action and social structure: The problem of embeddedness, American Journal of Sociology, 91, 481-510.

Hariyono, S. (2020). Falia Expression Protecting Environmental Ecosystem in Barangka District. Journal of Ethnic and Cultural Studies, 7(1), 79-98.

Haque, M. M., Belton, B., Alam, M. M., Ahmed, A. G., \& Alam, M. R. (2016). Reuse of fishpond sediments as fertilizer for fodder grass production in Bangladesh: Potential for sustainable intensification and improved nutrition. Agriculture, Ecosystems \& Environment, 216, 226236.

Haque, S. M. F., Choudhury, A., Adam, R., \& McDougall, C. (2020). Rapid assessment on gender dynamics, barriers, opportunities, and risks in agriculture and aquaculture sectors in northwestern Bangladesh. WorldFish.

Hemme, T., Garcia, O., \& Khan, A. R. (2004). A review of milk production in Bangladesh with particular emphasis on small-scale producers (Working Paper No. 7). Pro-Poor Livestock Policy Initiative. International Farm Comparison Network.

Islam, A. W. M. S., Hefazuddin, S., \& Rahman, M. H. (2003). Cattle. In S. Islam (Ed.), Banglapedia: National encyclopaedia of Bangladesh. Asiatic Society of Bangladesh.

Jabbar, M. A. (2010). Policy barriers for dairy value chain development in Bangladesh with a focus on the North West region, 138, 2016-2026.

Jäckering, L., Fischer, S., \& Kehlenbeck, K. (2019). A value chain analysis of baobab (Adansonia digitata L.) products in Eastern and Coastal Kenya. Journal of Agriculture \& Rural Development in the Tropics and Subtropics (JARTS), 120(1), 91-104.

Kabeer, N. (1988). Subordination and struggle: Women in Bangladesh, New Left Review, 168, 95.

Kabeer, N. (1991). Gender dimensions of rural poverty: Analysis from Bangladesh, The Journal of Peasant Studies, 18(2), 241-262.

Kabeer, N. (1994). Reversed realities: Gender hierarchies in development thought. Verso.

Kabeer, N. (1998). 'Money can't buy me love'? Re-evaluating gender, credit and empowerment in rural Bangladesh, IDS Discussion paper series, 363. IDS, UK.

Kabeer, N., Mahmud, S., \& Tasneem, S. (2011). Does paid work provide a pathway to women's empowerment? Empirical findings from Bangladesh (Working Paper 375). IDS, UK.

Kaplinsky, R., \& Morris, M. (2000). A handbook for value chain research. IDS.

Khan, M. J., Peters, K. J., \& Uddin, M. M. (2009). Feeding strategy for improving dairy cattle productivity in small farm in Bangladesh, Bangladesh Journal of Animal Science, 38(1-2), 67-85.

Kiambi, S., Onono, J. O., Kang'ethe, E., Aboge, G. O., Murungi, M. K., Muinde, P., Akoko, J., Momanyi, K., Rushton, J., Fèvre, E. M., \& Alarcon, P. (2020). Investigation of the governance structure of the Nairobi dairy value chain and its influence on food safety. Preventive Veterinary Medicine, 179, 105009.

Kuijpers, R. (2020). Integrated value chain development: Evidence from Bangladesh. Food Policy, 97, 101916. 
Kumar, D., \& Rajeev, P. V. (2016). Value chain: A conceptual framework. International Journal of Engineering \& Management Sciences, 7(1), 74-77.

Manso, T., Gallardo, B., \& Guerra-Rivas, C. (2016). Modifying milk and meat fat quality through feed changes. Small Ruminant Research, 142, 31-37.

Mazzucato, M. (2015). The entrepreneurial state: Debunking private vs. public sector myths. Anthem Press.

Merhaut, M. (2019). Theoretical studies focused on gender discrimination against Roma women in the Czech Republic. Journal of Ethnic and Cultural Studies, 6(1), 28-44.

Millogo, V., Sjaunja, K. S., Ouédraogo, G. A., \& Agenäs, S. (2010). Raw milk hygiene at farms, processing units, and local markets in Burkina Faso. Food Control, 21(7), 1070-1074.

Momsen, J. (2008). Women and Development in the Third World. Routledge.

Muzareba, A. M. (2018). A study on the imperative veterinary and related services providing actors in dairy value chain of Bangladesh: Reflections on some cases, Dhaka University Journal of Management, 12(2), 31-51.

Nang'ole, E., Mithöfer, D., \& Franzel, S. (2011). Review of guidelines and manuals for value chain analysis for agricultural and forest products. World Agroforestry Centre.

Nyokabi, S. N., de Boer, I. J., Luning, P. A., Korir, L., Lindahl, J., Bett, B., \& Oosting, S. J. (2021). Milk quality along dairy farming systems and associated value chains in Kenya: An analysis of composition, contamination and adulteration. Food Control, 119, 107482.

Oliver, S. P., Jayarao, B. M., \& Almeida, R. A. (2005). Foodborne pathogens in milk and the dairy farm environment. Foodborne Pathogens \& Disease, 2(2), 115-129.

Orwa, J. D., Matofari, J. W., Muliro, P. S., \& Lamuka, P. (2017). Assessment of sulphonamides and tetracyclines antibiotic residue contaminants in rural and peri urban dairy value chains in Kenya. International Journal of Food Contamination, 4(1), 1-11.

Phiri, B. S., Sakumona, M., Hang'ombe, B. M., Fetsch, A., \& Schaarschmidt, S. (2021). The traditional dairy value chain in Zambia and potential risk factors to microbiological food safety. Food Control, 124, 107885.

Prahalad, C. K. (2010). The fortune at the bottom of the pyramid: Eradicating poverty through profits. Pearson Education Inc.

Quisumbing, A. R., \& Roy, S. (2014). Assets, decision making, and time use: The gendered impacts of a dairy value-chain project in rural Bangladesh. SSRN. https://papers.ssrn.com/sol3/papers.cfm?abstract_id=2407176.

Rahman, H., Happy, F. A., Efan, A. H., \& Hera, M. H. R. (2019). The small-scale dairy value chain analysis: Challenges and opportunities for dairy development in Mymensingh district of Bangladesh. SAARC Journal of Agriculture, 17(2), 213-226.

Rasmussen, P., Barkema, H. W., Mason, S., Beaulieu, E., \& Hall, D. C. (2021). Economic losses due to Johne's disease (paratuberculosis) in dairy cattle. Journal of Dairy Science, 104(3), 3123-3143.

Savani, M., \& Stewart, A. (2019). Making market systems work for women dairy farmers in Bangladesh: A final evaluation of Oxfam's Gendered Enterprise and Markets Programme in Bangladesh. Oxfam GB.

Seymour, G., Malapit, H., \& Quisumbing, A. (2020). Measuring time use in developing country agriculture: Evidence from Bangladesh and Uganda. Feminist Economics, 26(3), 169-199.

Sherif, B. (2001). The ambiguity of boundaries in the fieldwork experience: Establishing rapport and negotiating insider/outsider status. Qualitative Inquiry, 7(4), 436-447. 
Sikira, A. N., Waithanji, E. M., Galie, A. \& Baltenweck, I. (2018). Gender aspects in the dairy value chain in Tanzania: A review of literature. Livestock Research for Rural Development, $30(4), 1-12$.

Silverman, D. (2015). Interpreting qualitative data, Sage.

Tan, A., \& Ngan, P. T. (2020). A proposed framework model for dairy supply chain traceability. Sustainable Futures, 2, 100034.

Treurniet, M. (2021). The potency of quality incentives: Evidence from the Indonesian dairy value chain. American Journal of Agricultural Economics. https://doi.org/10.1111/ajae.12176

Uddin, M. E., Pervez, A. K., \& Gao, Q. (2020). Effect of voluntary cooperativisation on livelihood capital of smallholder dairy farmers in the southwest of Bangladesh. GeoJournal, 1-20.

Uddin, M. J., Talukder, M. S., \& Aziz, T. (2015). Impact assessment of Bangladesh Bank's refinance scheme for financing agricultural \& non-farm rural borrowers of Bangladesh Krishi Bank and Rajshahi Krishi Unnayan Bank. Bangladesh Bank.

Van, L. E. J., Caputo, V., Nayga, J. R. M., \& Verbeke, W. (2014). Consumers' valuation of sustainability labels on meat. Food Policy, 49, 137-150.

\section{Notes on Contributors}

Abureza M. Muzareba serves as an associate professor in the Department of Marketing at the University of Dhaka. He developed interdisciplinary expertise by studying social science, business, and engineering. He has both industry and research experiences with organizations including HSBC, Care Bangladesh, USAID, IFPRI, UK Cabinet Office, Barnsley City Council, England, and the University of Sheffield. His research interests include value chain analysis, consumer behavior, marketing, e-learning, digital sociology, ICT4D, poverty reduction, and wellbeing.

Mubina Khondkar servers as a professor in the Department of Marketing at the University of Dhaka. She has interdisciplinary knowledge of marketing and development economics. She has both industry and research experiences with organizations including ANZ Grindlays Bank, Care Bangladesh, USAID, DFID, Concern, IFPRI, World Bank, SEDF, IFC, JICA, CIDA, UNICEF, BIDS, the University of Manchester, and the University of Cambridge. Her research interests include value chain analysis, marketing, poverty, microfinance, development economics, gender, and women's empowerment.

Manuscript received January 20, 2021

Final revision received April 5, 2021

Accepted April 14, 2021 